\title{
Improving the Efficiency of Green Roofs Using Atmospheric Water Harvesting Systems (An Innovative Design)
}

\author{
Behrouz Pirouz $^{1, *(\mathbb{D})}$, Stefania Anna Palermo ${ }^{2}$ and Michele Turco $^{2}(\mathbb{D}$ \\ 1 Department of Mechanical, Energy and Management Engineering, University of Calabria, \\ 87036 Rende, CS, Italy \\ 2 Department of Civil Engineering, University of Calabria, 87036 Rende, CS, Italy; \\ stefania.palermo@unical.it (S.A.P.); michele.turco@unical.it (M.T.) \\ * Correspondence: behrouz.pirouz@unical.it; Tel.: +39-0984-496542
}

Citation: Pirouz, B.; Palermo, S.A.; Turco, M. Improving the Efficiency of Green Roofs Using Atmospheric Water Harvesting Systems (An Innovative Design). Water 2021, 13, 546. https://doi.org/10.3390/w13040546

Academic Editor: Andreas

N. Angelakis

Received: 4 January 2021

Accepted: 15 February 2021

Published: 20 February 2021

Publisher's Note: MDPI stays neutral with regard to jurisdictional claims in published maps and institutional affiliations.

Copyright: (c) 2021 by the authors. Licensee MDPI, Basel, Switzerland. This article is an open access article distributed under the terms and conditions of the Creative Commons Attribution (CC BY) license (https:// creativecommons.org/licenses/by/ $4.0 /)$.

\begin{abstract}
Conventional green roofs, although having numerous advantages, could place water resources under pressure in dry periods due to irrigation requirements. Moreover, the thermal efficiency of green roofs could decrease without irrigation, and the plants could get damaged. Therefore, this study aims to improve the efficiency of conventional green roofs by proposing a new multipurpose green roof combined with fog and dew harvesting systems. The analysis determined that the average water use of green roofs in the summer (in humid regions) is about $3.7 \mathrm{~L} / \mathrm{m}^{2} /$ day, in the Mediterranean regions about $4.5 \mathrm{~L} / \mathrm{m}^{2} /$ day, and in arid regions about $2.7 \mathrm{~L} / \mathrm{m}^{2} /$ day. During the dry season, the average fog potential in humid regions is 1.2 to $15.6 \mathrm{~L} / \mathrm{m}^{2} /$ day, Mediterranean regions between 1.6 and $4.6 \mathrm{~L} / \mathrm{m}^{2} /$ day, and arid regions between 1.8 and $11.8 \mathrm{~L} / \mathrm{m}^{2} /$ day. The average dew potential during the dry season in humid regions is 0.1 to $0.3 \mathrm{~L} / \mathrm{m}^{2} /$ day, in the Mediterranean regions is 0.2 to $0.3 \mathrm{~L} / \mathrm{m}^{2} /$ day, and in the arid regions is 0.5 to $0.7 \mathrm{~L} / \mathrm{m}^{2} /$ day. The analysis of the suggested multipurpose green roof combined with fog/dew harvesting systems, in the summer, in three different climates, show that fog harvesting could provide the total water requirement of the green roofs, and that dew harvesting by PV (photo-voltaic) panels could provide 15 to $26 \%$ of the water requirements. Moreover, it could show a higher thermal impact on the building, higher efficiency in stormwater management, less dependence on the urban water network, and greater efficiency in decreasing urban air, water, and noise pollution. Finally, the novel green roof system could consume less water due to the shaded area by mesh and solar PVs and maximize the utilization of the roof area, as solar panels could be applied on the same green roof.
\end{abstract}

Keywords: green roofs; fog water harvesting; dew water harvesting; solar PV; sustainability

\section{Introduction}

Greening systems, such as green roofs, have several environmental [1,2], social, and economic benefits [3-6]. Moreover, these systems can increase biodiversity [7-9], improve water quality [10-14], decrease noise level [15-17], and increase life quality [18-20]. These systems are widespread in different climates-mostly for rainwater harvesting [21-25] and stormwater management [26-28] - by decreasing the peak of urban runoff [29-33].

The impact of green roofs as a natural cooling system is evident [34], and the water footprint of electricity and heat can be decreased by green roofs [35]. The thermal advantages of green roofs in the summer include mitigation of the heat island [36-43], decreasing roof temperature [44,45], and moderating roof temperature fluctuations during the warmest hours of the day; therefore, decreasing total energy demand [46-48]. The advantages of green roofs in winter include thermal performance through insulation [49] and urban runoff management as a low impact development (LID) technology [25,50]. However, one major element in cooling performance is the water content in the summer [51]. Water demands cannot rely on precipitation in the summer, and the irrigation of green roofs might be necessary [52]. In dry and semi-dry climates, and even those with annual rainfall 
of more than $1000 \mathrm{~mm}$, such as the Mediterranean climates, precipitation during the dry period could be scarce, or even less than $1 \mathrm{~mm}$ in some years [53,54].

The analysis of water conditions in several Mediterranean countries determined the benefits of non-conventional water resources, such as rainwater harvesting, Atmospheric (fog/dew) water harvesting, and even reverse osmosis (RO) [55]. The feasibility of atmospheric water harvesting methods has been approved in numerous geographical locations with different humidity levels [56-58]. However, before high investment programs are launched, experimental analysis on the local pilot system is recommended [59]. The worldwide analysis of fog harvesting systems confirmed fog harvesting potential, particularly in arid regions [60]. Fog harvesting potential depends on the mesh topology, wettability, and collector efficiency [56]. Another non-conventional water resource is dew water harvesting, which is different from fog harvesting, and means collecting droplets on surfaces with temperatures below the dew point [61]. Different dew harvesting methods include active cooling condensation, regenerated solar desiccant, and passive systems. [56]. The experimental analysis of a dew and rain harvesting system using plastic cover showed the dew contribution from total water was significantly high, about $26 \%$ [61]. In arid and semi-arid areas, the dew collection could be significant compared to the dry season's rainfall amount [62]. Dew is a critical water resource in the desert area, and the growth of vegetation depends on that $[63,64]$. Furthermore, the type of plant can affect the dew formation near the ground. The dew formation analysis near the plants, such as Haloxylon ammodendron, exhibited that the plant's canopy can increase dew formation frequency [65]. The dew formation could happen on PV (photo-voltaic) panels during the night and early morning [66]. The average emissivity of PV panels, between $75 \%$ and $90 \%$, is suitable for dew harvesting $[67,68]$.

\subsection{Green Roof Properties and Water Use in Different Climates}

Green roofs are usually divided into intensive green roof (IGR) and extensive green roof (EGR) [69]. This classification is due to the soil layer's depth (IGR has a soil layer depth of more than $15 \mathrm{~cm}$ while EGR has a depth of less than $20 \mathrm{~cm}$ ) and the maintenance. EGR requires low maintenance; irrigation applies rarely. Green roof design consists of several components from top to bottom, including a vegetation layer, a soil substrate, a filter layer (usually constructed as a geotextile), a drainage layer, a root barrier layer, and a waterproofing membrane [70]. The components, like the irrigation system, depends on the green roof type [71]. In Mediterranean climates, many studies emphasized that the environmental benefits of green roofs are more evident in the hot season than in the cold [72-78]. In these regions, energy-saving can also be reached (84\% in the hot season). In tropical climates, green solution adoption has demonstrated that environmental benefits have less impact than in the Mediterranean climates, but they were also relevant [79-83]. The rate of energy-saving in these regions can reach an average of $65 \%$. In arid climates, results were not promising, but energy-saving could reach $52 \%$ in the cold season, while energy-saving in the hot season was very low $[84,85]$. The same behavior can be assumed for continental climates, where no relevant energy-saving was recorded in literature, especially in the hot season [86]. However, the thermal impacts of green roofs, especially in the summer, depending on the irrigation and dry periods, could negatively affect thermal efficiency [51,87-89].

Water use by green roofs depends on several factors, including climate type, annual rainfall and distribution, vegetation type, green roof type (e.g., IGR requires more water than EGR), average temperature, and relative humidity [71]. Brunetti et al. [90] studied the effect of different daily irrigation scenarios for a non-vegetated green roof in a Mediterranean climate, considering that the daily irrigation volume was estimated at $7 \mathrm{~L} /$ day $\mathrm{m}^{2}$. Schweitzer and Erell [91] estimated that the water use in irrigation for an extensive green roof in a Mediterranean climate ranges from 2.6 to $9.0 \mathrm{~L} / \mathrm{m}^{2}$ per day. Peng and Jim [92] set up an automatic sprinkler irrigation system for the green roof in a humid-subtropical climate that provided supplementary water supply at $5 \mathrm{~L} / \mathrm{m}^{2}$ per day in the summer, sus- 
taining an average soil moisture content of about $0.3 \mathrm{~m}^{3}$ water $/ \mathrm{m}^{3}$ soil for the experimental investigations on an EGR.

\subsection{Potential of Atmospheric Water Harvesting Methods}

\subsubsection{Dew Collection Potential in Different Climates}

Beysens et al. [61] investigated the potential of fog and dew harvesting, and their analysis determined that fog and dew harvesting could count as a water source in many geographical regions, especially those with low precipitation and in dry seasons. In another study, Beysens [64] determined that the dew potential could be estimated using wind speed, air temperature, dew point temperatures, and cloud cover. Tomaszkiewicz et al. [62] explored the dew yield during the dry season in the Mediterranean region. Their analysis determined that the monthly dew could be at least $1.5 \mathrm{~mm}$ and exceed $2.8 \mathrm{~mm}$ at the end of the dry season, whereas the precipitation is less than $1 \mathrm{~mm}$. In another study, Tomaszkiewicz et al. [93] analyzed the feasibility of using dew harvesting for agricultural purposes during the dry season, and their results showed that the dew events occur in $43 \%$ of nights in the dry season, and a dew harvesting system with a size of $2 \mathrm{~m}^{2}$ could produce $4.5 \mathrm{~L} /$ month, which is sufficient for the irrigation of tree seedlings.

Maestre-Valero et al. [94] analyzed the performance of dew collecting in a semi-arid region in Spain and their results showed that the dew yield was lower in a wind speed higher than $1.5 \mathrm{~m} / \mathrm{s}$ and the $\mathrm{RH}$ (relative humidity) less than $75 \%$. In another study, Maestre-Valero et al. [95] determined that the dew yield prediction is highly dependent on RH. In more recent research by Maestre-Valero et al. [96], they determined that the water thermal inertia from the remaining water on the surface could strongly limit dew formation, and drainage water could improve efficiency. Sharan et al. [97] analyzed the efficiency of an extensive dew collection system for a semi-arid area of India. They analyzed a large dew condenser with a surface of $850 \mathrm{~m}^{2}$ from plastic foils installed on the ground, with a slope of $30^{\circ}$ from horizontal, and the results show the annual output of $6545 \mathrm{~L} /$ day. The maximum collected amount in one night was 251.4 L. Tuure et al. [29] characterized different dewharvesting materials in Kenya, including PVC and PE. The analysis determined that dew harvesting could be counted as a continuous water resource in the dry season, and the cumulated dew yields in arid conditions were between 18.9 and $25.3 \mathrm{~mm}$, with average dew per night between 0.052 and $0.069 \mathrm{~mm} / \mathrm{m}^{2}$. In another study, Tuure et al. [98] analyzed the potential of a passive dew collection system using plastic foil. The analysis determined that the color and type of plastic foils affect the yield, about $15 \%$.

Gandhidasan and Abualhamayel [99] proposed a new radiative cooled method of dew harvesting. Their result shows that the maximum possible dew collection could be in the condition of high relative humidity and clear sky. Moreover, by increasing the wind speed in high relative humidity, the dew collection rate also increases. Galek et al. [100] compared the frequency of dew and hoarfrost formations in urban conditions in Wroclaw, Poland, by use of passive radiative condensers that were 96 hoarfrost and 222 dew events in around two years. The formation and efficiency for both were similar, but dew deposition was nearly three times higher than hoarfrost. Zhuang and Zhao [65] investigated the influence factors in dew formation and the total potential in a desert oasis in China. Their analysis determined that the average amount of dew in summer is about $0.13 \mathrm{~mm} /$ day, and the total amount from July to October is equal to $16.1 \mathrm{~mm}$.

Most of the materials recommended for atmosphere water harvesting have hydrophobic nature, such as polypropylene (pp), polyethylene (PE), stainless steel, and nylon. However, it is possible to improve the properties with a coating. Pinheiro et al. [101] investigated a super-hydrophobic polyethylene (PE) surface with vertically aligned carbon nanotube coating for dew condensation, and the new coating surface increased the efficiency.

Liu et al. [102] investigated a new radiative cooling system by applying advanced nanofabrication technologies to improve water harvesting efficiency by polytetrafluoroethylene (PTFE) foil. The results showed a significant improvement in the performance of the new system. Furthermore, the analysis of adding a simple hydrophilic coating on a 
durable enhanced specular reflector-metal surface exhibits an increase of efficiency of about $72.7 \%$. Xu et al. [103] analyzed the cooling performance of a building in Beijing, in a warm and humid climate, via a novel dew point cooler (DPC). The analysis showed the system would be useful in $\mathrm{RH}$, by more than $50 \%$ in the summer, and could decrease electricity consumption during peak hours. Pandelidis et al. [104] investigated the performance of a hybrid dew-point evaporative air conditioner system, and the results determined that the system could cover about $95 \%$ of cooling loads.

Dew collection methods can be applied in many geographical locations, while fog just forms in particular atmospheric conditions [105]. The high RH, low wind speed, and clear sky are three suitable atmospheric conditions for dew harvesting [106], and the collected dew in the arid area might exceed the precipitation [107]. Another study on China's desert climate shows the impacts of temperature, $\mathrm{RH}$, and wind speed on dew characteristics. The calculated thresholds for dew formation in this study are the wind speed of less than $4.27 \mathrm{~m} / \mathrm{s}$ and an $\mathrm{RH}$ of more than 50\% [65]. In the radiative dew condenser (RDC) method, the dew yield depends on the cooling power gradient by infrared irradiation towards the sky, which will increase in the clear sky. The International Organization for Dew Utilization (OPUR) recommends using plastic foils, such as low-density polyethylene (LDPE) in the passive dew collection. LDPE's emissivity is high due to the added materials, such as $2 \%$ $\mathrm{BaSO}_{4}$ and $5 \% \mathrm{TiO}_{2}$ [108].

Furthermore, surface wettability affects the efficiency of dew harvesting. In dew harvesting methods, the capture is due to the nucleation energy affected by the wettability, so the surface with higher wettability would show better efficiency [109]. One technique to increase a surface's wettability is coating by using carbon nanotubes, which can naturally change the super-hydrophobic properties to super-hydrophilic [110] due to the unique physical and chemical properties of carbon nanotubes [111]. Several factors need to be considered to optimize the dew harvesting efficiency [61]:

- Use of condensing surface with maximum emitting of the infrared wavelength;

- Use of condensing surface with high reflectivity to avoid heat absorption during the day;

- Use of condensing surface with high hydrophilic and wettability property;

- Use of insulation to decrease the heat inertia of the condensing surface;

- Decrease of the wind effect to avoid evaporation from the condenser.

The dew's formation depends on the surface cooling power and the gradient between the surface emissivity and sky radial emissivity [112]. According to the Stefan-Boltzmann law, the irradiation can reach roughly $100 \mathrm{~W} / \mathrm{m}^{2}$ in a clear night [113]. Therefore, the maximum theoretical dew collection can be calculated around $0.1 \mathrm{~L} / \mathrm{m}^{2}$ per hour and depends on the number of condensing hours, which can be determined for one night (i.e., for $8 \mathrm{~h}$ equal to $0.8 \mathrm{~mm}$ per night) [114]. However, the maximum obtained dew in the previous case studies was nearly half, and $0.38 \mathrm{~mm}$ per night [115].

\subsubsection{Fog Harvesting Potential in Different Climates}

Standard fog collectors (SFCs) are between 1 and $1.5 \mathrm{~m}^{2}$ and installs on $2 \mathrm{~m}$ above the ground level [116]. Large fog collector (LFC) sizes are between 40 and $48 \mathrm{~m}^{2}$, with the width to height ratio of around 2.5-3, with the same installation level of SFCs [117]. The analysis in Egypt and Morocco with arid climates determined fog harvesting effectiveness to improve water scarcity $[118,119]$. The efficiency of the fog harvesting systems would depend on visibility [109], contact angle [120], wind velocity [121], mesh type, fog water content, droplet size [122], geometrical shapes of the mesh [123], and wettability of mesh [120]. Fog harvesting efficiency could decrease in the high-speed wind [124] and could increase by improving the hydrophobic nature of mesh $[125,126]$ through super-hydrophobic materials, such as $\mathrm{TiO}_{2}, \mathrm{ZnO}$, or fluorinated nanofibers for coating mesh [127,128]. Pinheiro et al. [129] analyzed the use of vertically aligned carbon nanotubes (VACNTs) for fog harvesting. Their results determined the high efficiency of the method since water collection reached about $30\left(\mathrm{~L} / \mathrm{m}^{2}\right) / \mathrm{h}$. The analysis shows that fog harvesting capacity using a coated mesh could be about $2 \mathrm{~L} / \mathrm{m}^{2}$ even in a mild fog with a wind speed of $2 \mathrm{~m} / \mathrm{s}$ [120]. An additional important 
factor is the sustainability of methods [130-132], which means installation structures, water collectors, and mesh materials [133].

There are many published papers about green roofs and atmospheric water harvesting methods. However, analysis of a combined design using dew and fog harvesting water in irrigation of green roofs received less attention. The key focus on conventional green roofs are stormwater management, landscape, and thermal impacts. The remaining issues are the water requirements in the summer that could negatively affect the thermal impacts and the utilization of the roof area for other purposes, such as PV panels.

Therefore, this study addresses improving conventional green roof usage and efficiency by proposing a new, multipurpose green roof with fog and dew harvesting systems. In this regard, this study's main goal is to analyze the new proposed system's potential in different climates to decrease the dependency of green roofs on urban water resources, especially in dry periods.

\section{Materials and Methods}

\subsection{The Analysis Method}

The analysis flowchart is presented in Figure 1.

As shown in the flowchart, the analysis was done in three climates: humid, Mediterranean, and dry. At first, the properties and issues in the conventional green roofs were determined. Second, the water requirements of the green roofs and fog/dew harvesting potential in the selected climates were determined by analyzing different case studies. The data are based on numerous case studies in the selected climates. According to the analysis of the selected case studies, the ranges for green roof water requirements and the ranges for fog/dew yield have been provided.

The results of the second part demonstrate how the innovative design could be made. In the third part, a multipurpose green roof combined with fog/dew water harvesting systems was proposed, and the elements are explained. The calculations for the suggested multipurpose green roof system for a roof with an area of $100 \mathrm{~m}^{2}$ in three different climates are shown in the fourth part. The results show that the share of AWH (atmospheric water harvesting) systems in total water requirements of green roofs. From the results of this section, the new, proposed multipurpose green roof was compared with the conventional green roofs.

At the end, the applications and the newly suggested, possible main advantages of the multipurpose green roof are explained.

\subsection{The Water Requirements of Green Roofs in Different Climates}

The water use of green roofs in different climate types are presented in Table 1.

Table 1. The water requirements of the green roofs in different climates.

\begin{tabular}{|c|c|c|c|c|}
\hline Climate & Location & Size $\left(\mathrm{m}^{2}\right)$ & $\begin{array}{l}\text { Water Requirements in the } \\
\text { Summer }\left(\mathrm{L} / \mathrm{d} / \mathrm{m}^{2}\right)\end{array}$ & Reference \\
\hline Humid subtropical & City of Hong Kong (China) & 484 & 5.0 & [92] \\
\hline Subtropical and marine regions & Kobe (Japan) & 0.81 & 6.17 & [134] \\
\hline Humid continental & Beijing (China) & - & 1.24 & [135] \\
\hline Temperate oceanic climate & Neubrandenburg(Germany) & 0.25 & $3-5$ & [136] \\
\hline \multirow{4}{*}{ Mediterranean } & Rende (Italy) & 55 & 7.0 & [90] \\
\hline & Tel Aviv University & - & $4.5-7.0$ & [91] \\
\hline & \multirow{2}{*}{ Athens (Greece) } & 1.17 & 2.08 & [137] \\
\hline & & 0.24 & 1.96 & [138] \\
\hline Semi-arid & Colorado (USA) & - & 2.67 & [139] \\
\hline
\end{tabular}




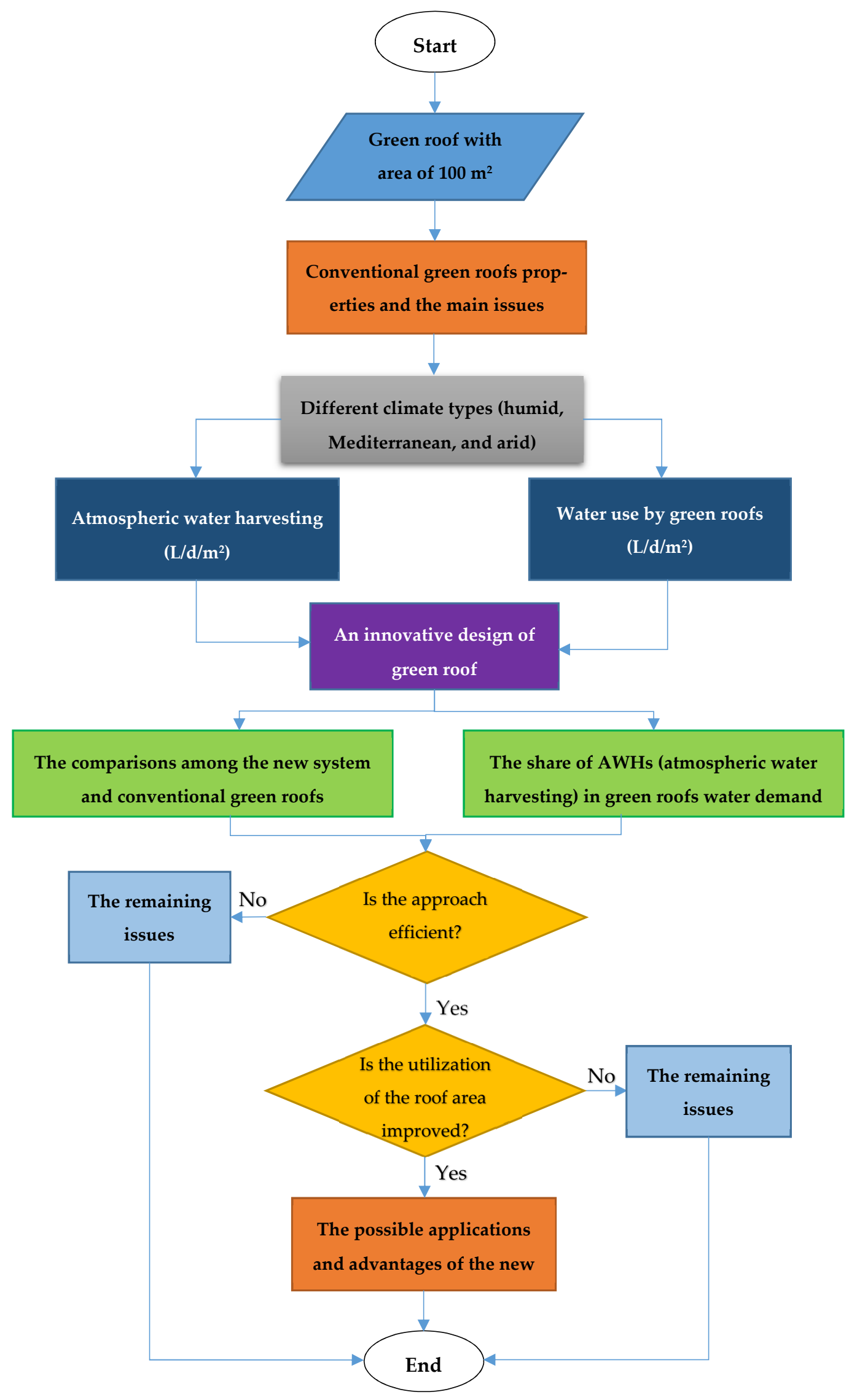

Figure 1. The analysis flowchart. 


\subsection{The Potential of Atmospheric Water Harvesting in Different Climates}

The potential of dew and fog water harvesting in different climate types are presented in Tables 2 and 3.

Table 2. Potential of dew harvesting in different climates.

\begin{tabular}{|c|c|c|c|c|c|c|}
\hline Climate & Location & Collector Material & E (\%) & $\mathrm{T}(\mathrm{mm})$ & Yield $\left(\mathrm{mm} / \mathrm{m}^{2}\right.$ Year) & Reference \\
\hline \multirow{3}{*}{ Semi-arid coastal } & \multirow{3}{*}{ India (Kothara) } & PETB & 0.83 & 0.3 & 19.4 & \multirow{3}{*}{ [140] } \\
\hline & & Galvanized iron & 0.23 & 1.5 & 15.6 & \\
\hline & & Aluminum & 0.09 & 1.5 & 9 & \\
\hline Semi-arid & India (Panandhro) & Plastic foil & 0.94 & - & 7.7 & [97] \\
\hline \multirow{3}{*}{$\begin{array}{l}\text { Mediterranean } \\
\text { Semi-arid }\end{array}$} & \multirow{2}{*}{ Spain (Cartagena) } & WSF & $0.87-0.89$ & - & 17.36 & \multirow{2}{*}{ [94] } \\
\hline & & $\mathrm{BF}$ & 0.99 & 0.15 & 20.76 & \\
\hline & Lebanon (Beiteddine) & РETB & 0.83 & 0.3 & 15.2 & [93] \\
\hline \multirow{2}{*}{ Mediterranean } & France (Corsica) & PETB & 0.83 & 0.3 & 25.68 & {$[141,142]$} \\
\hline & Croatia (Bis`evo) & Plastic cover & - & - & 14.7 & [61] \\
\hline Marine tropical & Tahiti Island & PTFE & - & 1.05 & 24.82 & [143] \\
\hline Humid continental & Poland (Wroclaw) & $\mathrm{PE}$ & - & - & 0.1 per day & [100] \\
\hline \multirow{5}{*}{ Arid } & \multirow{3}{*}{ Kenya (Maktau) } & PEB & 0.927 & - & 19.4 & \multirow{3}{*}{ [144] } \\
\hline & & PEW & 0.975 & - & 19.6 & \\
\hline & & PVC & 0.965 & - & 22.3 & \\
\hline & Saudi Arabia (Dhahran) & $\mathrm{PE}$ & - & - & 0.22 in one night & [99] \\
\hline & Morocco (15 cities) & Standard passive condensers & - & - & $0.3-18.1$ & [119] \\
\hline
\end{tabular}

E: emissivity; T: thickness; WSF: white hydrophilic foil; BF: low-cost black polyethylene foil; $\mathrm{PETB}$ : polyethylene mixed with $5 \% \mathrm{TiO}_{2}$ and $2 \%$ $\mathrm{BaSO}_{4}$; PTFE: polytetrafluoroethylene; PEB: polyethylene black; PEW: polyethylene white; PVC: polyvinyl chloride; PE: polyethylene foil.

Table 3. Potential of fog water harvesting systems in different climates.

\begin{tabular}{|c|c|c|c|c|c|}
\hline Climate Type & Location & Elevation $(\mathrm{m})$ & $\begin{array}{l}\text { Harvested Water } \\
\text { (L/m²/fog day) }\end{array}$ & $\begin{array}{l}\text { Harvested Water in } \\
\text { Summer (L/day) }\end{array}$ & Reference \\
\hline \multirow{4}{*}{ Hot Desert } & Chile (Alto Patache) & 700 & $6-7$ & - & {$[145,146]$} \\
\hline & Chile (Seashores, 0-12 km) & 650 & 7 & - & [147] \\
\hline & Iran (Chabahar) & 7 & 8.6 & - & [148] \\
\hline & Cape Verde & $750-1400$ & $3-75$ & - & [149] \\
\hline Sub-Tropical Arid & Iran (Abadan) & 3 & 6.7 & - & [150] \\
\hline \multirow{2}{*}{ semi-arid } & Morocco & 1225 & 10.5 & - & [151] \\
\hline & South Africa & 1600 & - & - & [152] \\
\hline Arid Tropical & Peru & 800 & 11.8 & - & [153] \\
\hline \multirow[t]{2}{*}{ Tropical } & Guatemala (Tojquia) & 3300 & $\begin{array}{l}3.8 \\
4.2\end{array}$ & $\begin{array}{l}- \\
-\end{array}$ & $\begin{array}{l}{[117]} \\
{[154]}\end{array}$ \\
\hline & Yemen & 1800 & 4.5 & - & [155] \\
\hline Sub-tropical & Nepal (Katmandu) & 1400 & 1.8 & - & [156] \\
\hline Mediterranean & Italy (Milan) & 120 & 3.3 & - & [157] \\
\hline $\begin{array}{c}\text { Mediterranean } \\
\text { (Coastal area) }\end{array}$ & $\begin{array}{l}\text { Spain (Peñagolosa) } \\
\text { Spain (Monduver) } \\
\text { Spain (Bartolo) } \\
\text { Spain (Montgo) }\end{array}$ & $\begin{array}{l}1193 \\
843 \\
763 \\
670\end{array}$ & $\begin{array}{c}2.9 \\
7.3 \\
2 \\
7\end{array}$ & $\begin{array}{l}2.5 \\
1.6 \\
1.4 \\
4.6\end{array}$ & [124] \\
\hline $\begin{array}{l}\text { Cold and humid } \\
\text { Warm and humid }\end{array}$ & Different sites & - & $\begin{array}{l}0.05 \mathrm{~L} / \mathrm{h} \\
0.65 \mathrm{~L} / \mathrm{h}\end{array}$ & - & [158] \\
\hline Different climates & Different sites & - & $3.1-15.6$ & - & [56] \\
\hline
\end{tabular}




\section{Results}

3.1. A New Multipurpose Green Roof with Fog and Dew Harvesting Systems

The new proposed green roof with fog and dew harvesting systems are presented in Figures 2-4. Figure 5 shows the location of the fog harvesting mesh and solar panels in the north and south hemispheres.

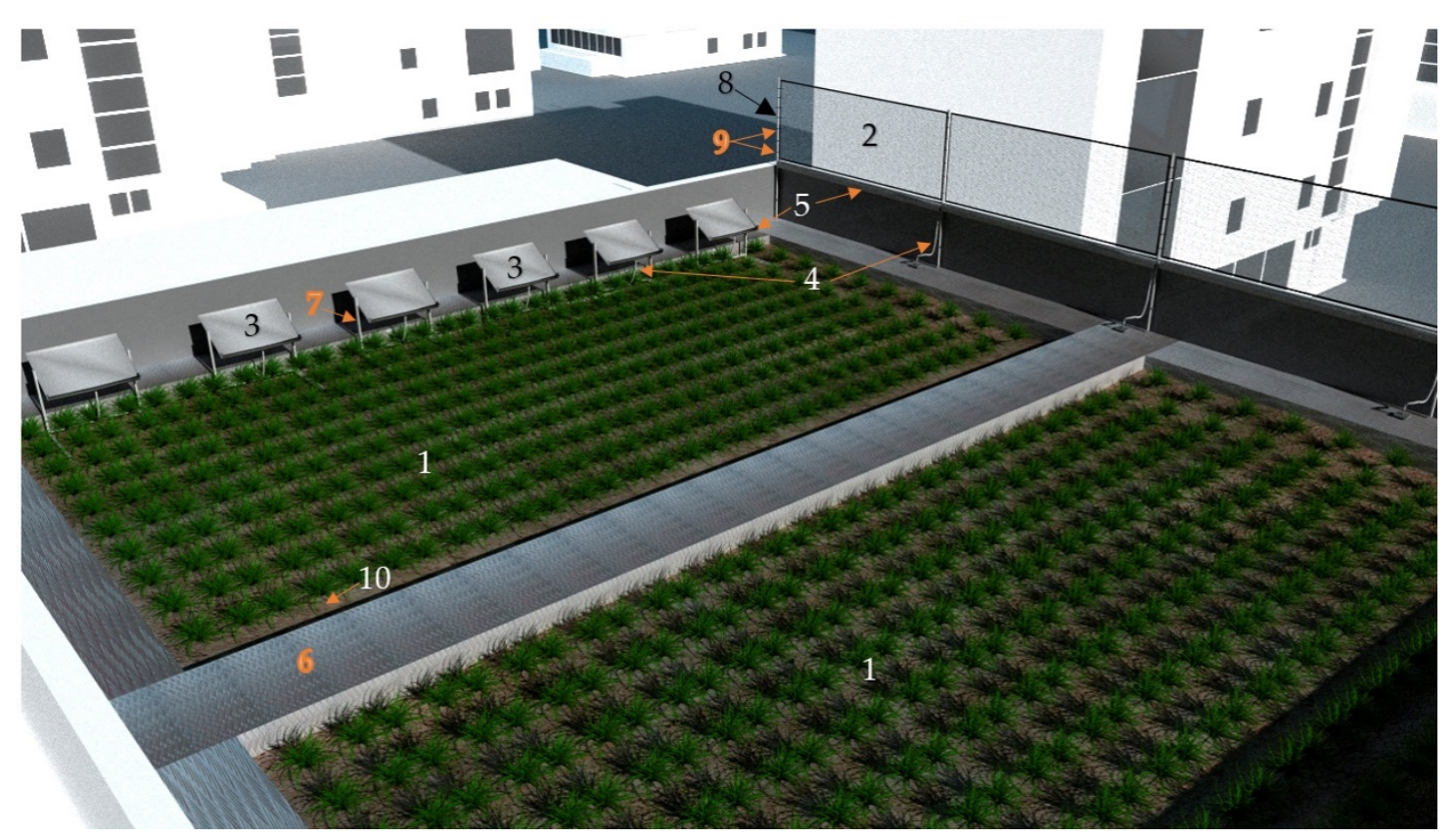

Figure 2. The new design of the green roof with atmospheric water harvesting systems. 1-green roof plants, 2-mesh for fog harvesting, 3-dew collector plate, 4-collector pipe, 5-harvested water collector duct, 6-duct for pipes, 7-metal base for fixing dew collector plate, 8-metal base for mesh installation, 9-metal clamp to fix the mesh, 10—soil.

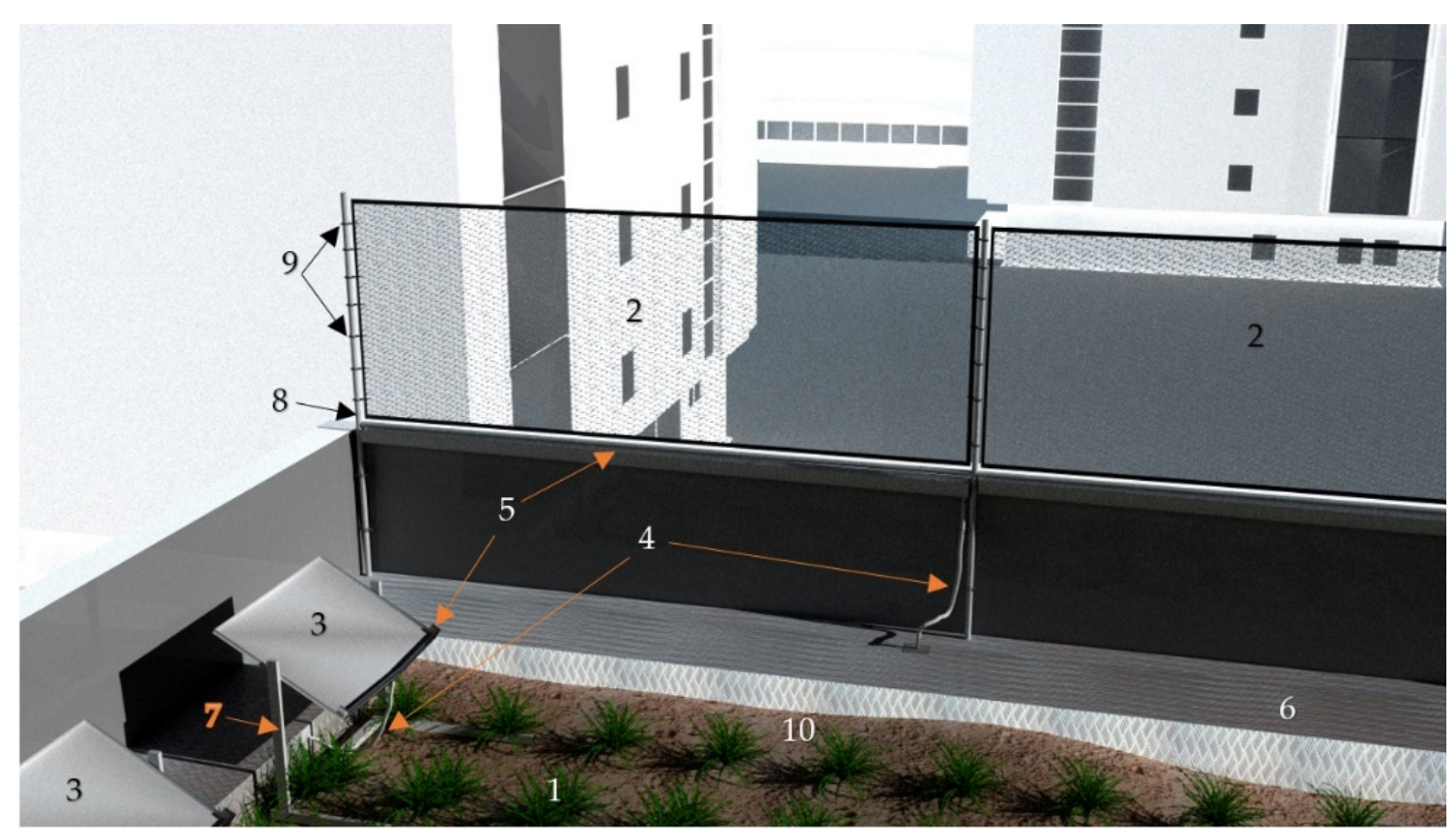

Figure 3. The main elements of the new green roof system. 


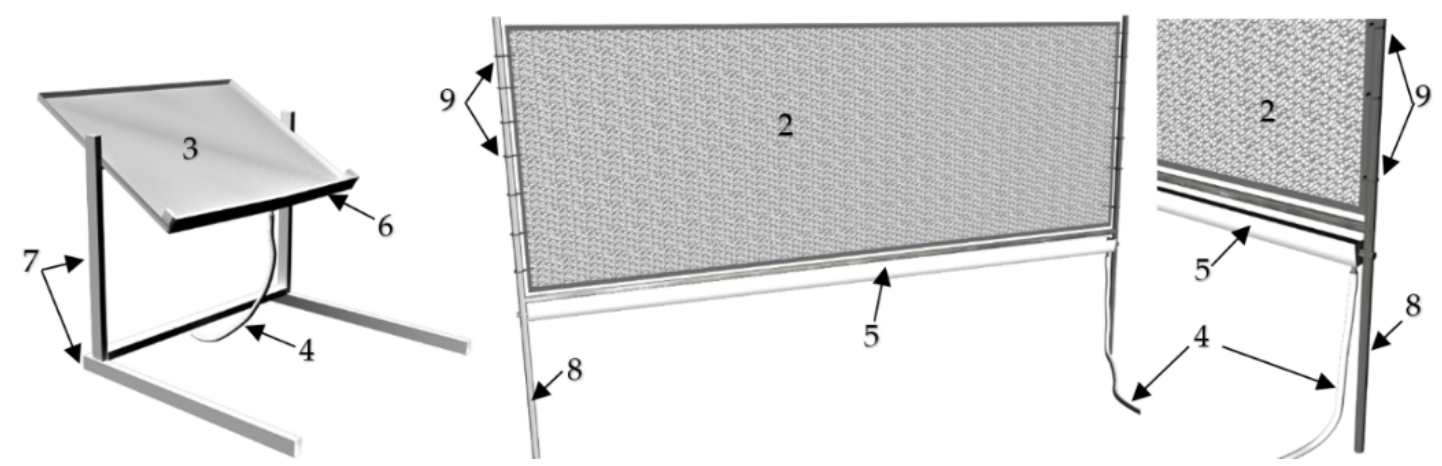

Figure 4. The fog and dew harvesting systems in the new green roof system.

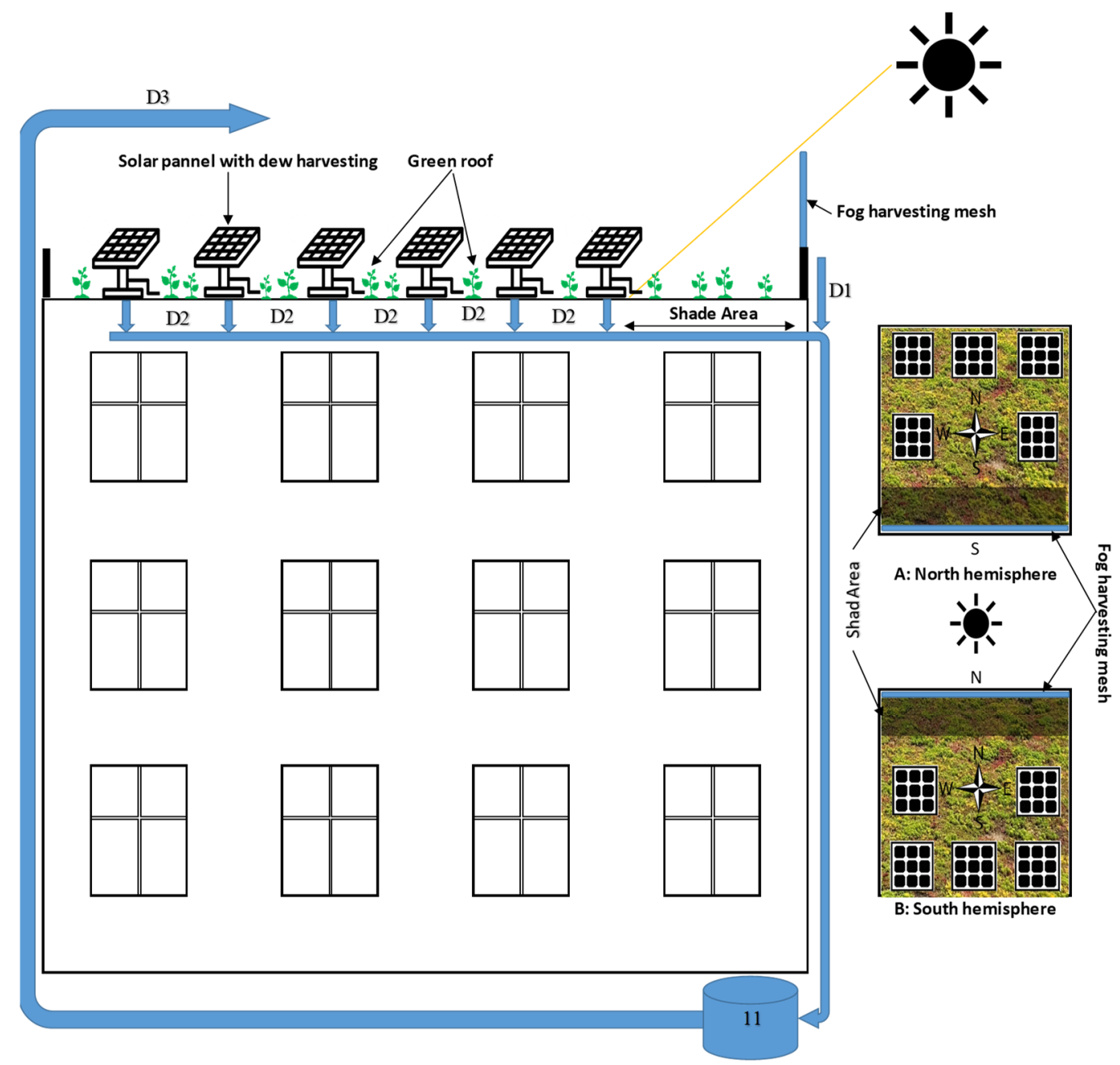

Figure 5. Location of the fog harvesting mesh and solar panels (for dew harvesting) in the north and south hemispheres, D1-harvested fog water to the storage tank, D2 - harvested dew water to the storage tank, D3 - the way of using harvested water for irrigation of the green roof or other not-potable usages in the buildings, 11 -water storage tank with filters.

As shown in Figures 2-5, the novel green roof would benefit from fog harvesting (by transparent mesh) and dew harvesting (by solar panels); it would depend less on urban water resources for irrigation, increasing the thermal advantages (and decreasing the negative points) of the green roof. The procedures are as follow:

- In the fog days, the transparent mesh placed on the roof side (i.e., in the northern hemisphere is the south side of the roof, and in the southern hemisphere is the north 
side of the roof) would harvest fog water. The harvested water would be gathered through the collector ducts and stored in the water storage tank with a filter. In case of more water requirements, the fog mesh could also be installed on all sides, but would create more shaded areas on the roof and might negatively affect solar PV efficiency.

- Solar PVs would collect dew water during the nights with a relative humidity of more than $50 \%$. The harvested dew would be transferred to the water storage tank with a filter.

\subsubsection{The Main Elements in the New Green Roof System}

The main elements in the new green roof system include:

- A green roof with dew and fog harvesting system;

- Fog harvesting mesh, a double-layer transparent mesh coated with hydrophobic materials $\left(\mathrm{ZnO}, \mathrm{BaSO}_{4}\right.$, or $\left.\mathrm{TiO}_{2}\right)$;

- Dew collector plates that are solar PV panels (could produce electricity during the days and water during the nights);

- Water collector pipes;

- Water collector ducts;

- Metal base for fixing dew and mesh systems;

- Water storage tank with a filter for the green wall's irrigation and other non-potable usages.

\subsubsection{The Possible Applications of the New Multipurpose Green Roof System}

The possible applications of the new multipurpose green roof system could do the following:

- Improve the thermal efficiency of the buildings and factories;

- Decrease the water consumption in conventional green roofs and improve the efficiency in decreasing noise, water, and air pollutions;

- Provide water for irrigation of green roofs beside other not-potable water usages in the buildings and factories;

- Optimize the roof area for using both green roof and solar PV panels;

- Improve the sustainability of buildings, factories, and municipalities.

\subsection{Analysis of the Proposed System for a Green Roof with an Area of $100 \mathrm{~m}^{2}$}

In this section, we analyzed the potential of the suggested multipurpose green roof in three climates. The considered fog mesh has a height of $2.5 \mathrm{~m}$, and we analyzed the installation of the mesh on one-side, two-sides, and four-sides of the roof area. The considered dew collectors are PV panels with installation in $25 \%, 50 \%$, and $100 \%$ of the roof area.

The average water use in green roofs in the summer is according to Section 1.1 and Table 1:

- In the humid regions: 1.2 to $6.2 \mathrm{~L} / \mathrm{m}^{2} /$ day;

- In the Mediterranean regions: 2 to $7 \mathrm{~L} / \mathrm{m}^{2} /$ day;

- In the arid regions (with drought-tolerant landscaping plants): $2.7 \mathrm{~L} / \mathrm{m}^{2} /$ day. Table 2:

The average dew potential during the dry season is according to Section 1.2.1 and

- In the humid regions: 0.1 to $0.3 \mathrm{~L} / \mathrm{m}^{2} /$ day;

- In the Mediterranean regions: 0.2 to $0.3 \mathrm{~L} / \mathrm{m}^{2} /$ day;

- In the arid regions: 0.5 to $0.7 \mathrm{~L} / \mathrm{m}^{2} /$ day.

The average fog potential during the dry season is according to Section 1.2.2 and Table 3:

- In the humid regions: 1.2 to $15.6 \mathrm{~L} / \mathrm{m}^{2} /$ day;

- In the Mediterranean regions: 1.6 to $4.6 \mathrm{~L} / \mathrm{m}^{2} /$ day;

- In the arid regions (seashores or high elevation): 1.8 to $11.8 \mathrm{~L} / \mathrm{m}^{2} /$ day. 
The calculations for the suggested multipurpose green roof system for a roof with an area of $100 \mathrm{~m}^{2}$ in three different climates are presented in Table 4.

Table 4. Water use and fog/dew harvesting in the new multipurpose green roof with an area of $100 \mathrm{~m}^{2}$.

\begin{tabular}{|c|c|c|c|c|c|c|c|}
\hline \multirow[t]{2}{*}{ Climate } & \multirow{2}{*}{$\begin{array}{l}\text { Water Use by Green } \\
\text { Roof }\left(\mathrm{L} / \mathrm{m}^{2} / \text { day }\right)\end{array}$} & \multicolumn{3}{|c|}{$\begin{array}{l}\text { Fog Harvesting Potential } \\
\text { (the Mesh Area in Each Side of the } \\
\left.\text { Roof }=10 \times 2.5=25 \mathrm{~m}^{2}\right)\left(\mathrm{L} / \mathrm{m}^{2} / \text { day) }\right.\end{array}$} & \multicolumn{3}{|c|}{$\begin{array}{l}\text { Dew Harvesting Potential (\% of the Roof Area) } \\
\left(\mathrm{L} / \mathrm{m}^{2} / \text { day }\right)\end{array}$} \\
\hline & & $\begin{array}{l}1 \text { Side } \\
\left(25 \mathrm{~m}^{2}\right)\end{array}$ & $\begin{array}{l}2 \text { Sides } \\
\left(50 \mathrm{~m}^{2}\right)\end{array}$ & $\begin{array}{l}\text { 4 Sides } \\
\left(100 \mathrm{~m}^{2}\right)\end{array}$ & $\begin{array}{c}25 \% \\
\left(25 \mathrm{~m}^{2}\right)\end{array}$ & $\begin{array}{c}50 \% \\
\left(50 \mathrm{~m}^{2}\right)\end{array}$ & $\begin{array}{c}100 \% \\
\left(100 \mathrm{~m}^{2}\right)\end{array}$ \\
\hline Humid & $120-620$ & $30-390$ & $60-780$ & $120-1560$ & $2.5-7.5$ & $5-15$ & $10-30$ \\
\hline Mediterranean & $200-700$ & $40-115$ & $80-230$ & $160-460$ & 5-7.5 & $10-15$ & $20-30$ \\
\hline Arid & 270 & $45-295$ & $90-590$ & $180-1180$ & $12.5-17.5$ & $25-35$ & $50-70$ \\
\hline
\end{tabular}

\section{Discussion}

According to the literature review analysis, the performance of green roofs mainly depends on the type of green roof, the climate type, and the irrigation amount. The energysaving differs from $84 \%$ in Mediterranean climates to $52 \%$ in arid climates. However, the thermal impacts, especially in the summer, depends on the irrigation, and dry periods could negatively affect the thermal efficiency. An intensive green roof (IGR) requires more water than an extensive green roof (EGR). The water use of an extensive green roof in a humid-subtropical climate is about $5 \mathrm{~L} / \mathrm{m}^{2} /$ day and in a Mediterranean climate ranges from 2.6 to $9.0 \mathrm{~L} / \mathrm{m}^{2} /$ day, averaging approximately $7 \mathrm{~L} / \mathrm{m}^{2} /$ day in the summer.

The analysis of fog and dew harvesting in many geographical regions determined the potential as a water source, especially in dry periods, to improve water scarcity. In Mediterranean regions, dew events could occur in around $43 \%$ of nights in the dry season; the dew yield during the dry season is at least $1.5 \mathrm{~mm}$ and exceeds $2.8 \mathrm{~mm}$ at the end of the dry season, whereas the precipitation could be less than $1 \mathrm{~mm}$. The values in the dry season's semi-arid regions are between 18.9 and $25.3 \mathrm{~mm}$, and in a desert in summer about $0.13 \mathrm{~mm} /$ day, and the total amount from July to October about $16.1 \mathrm{~mm}$. Dew water harvesting mainly depends on wind speed, condenser temperature, and relative humidity. Condenser temperature can decrease at night by a surface with high emissivity, meaning maximum reflectivity and emitting the infrared wavelength. The analysis shows RH of more than $50 \%$ and emissivity of more than 0.8 could be suitable for having a satisfactory yield. However, the wettability also affects the water capture and could be increased by coating materials, such as $\mathrm{BaSO}_{4}$ and $\mathrm{TiO}_{2}$. The fog harvesting system efficiency depends on several factors, mainly wind velocity, type, shapes, and mesh wettability. According to the previous studies, the potential of fog harvesting is about $3.1-15.6 \mathrm{~L} / \mathrm{m}^{2} /$ fog day in different climates. More specifically, about $7 \mathrm{~L} / \mathrm{m}^{2} /$ day in a desert with an elevation of about $650 \mathrm{~m}$, about $10 \mathrm{~L} / \mathrm{m}^{2} /$ day in arid regions with an elevation of $1000 \mathrm{~m}$, and $2-7.3 \mathrm{~L} / \mathrm{m}^{2} /$ day in Mediterranean climates with elevations more than $120 \mathrm{~m}$.

Results of the calculations for the suggested multipurpose green roof combined with fog and dew harvesting systems for a roof with a size of $100 \mathrm{~m}^{2}$ in three different climates are as follows:

- In humid climates, the fog mesh can provide 5 to $1300 \%$ of the water requirements of green roofs, while dew collection by PV panels could be 0.4 to $25 \%$ of the water requirements;

- In Mediterranean climates, the fog mesh can provide 6 to $230 \%$ of the water requirements of green roofs, while dew collection by PV panels could be 1 to $15 \%$ of the water requirements;

- In arid climates, the fog mesh can provide 17 to $437 \%$ of the water requirements of green roofs, while dew collection by PV panels could be 5 to $26 \%$ of the water requirements. 


\subsection{The Comparisons among the New Multipurpose Green Roof System and the Conventional Green Roofs}

The comparisons among the new multipurpose green roof combined with fog/dew harvesting systems and the conventional green roofs are as follows:

- In the conventional green roof system, the focuses are stormwater management, thermal impacts (that decrease with water issues in dry period), and landscape. However, in the new multipurpose green roof, fog harvesting mesh could improve the thermal impacts, increase stormwater management, decrease the noise and air pollution, and protect the plants from direct sunlight by creating a shaded area.

- The conventional green roofs are dependent on the urban water network for irrigation in dry periods. However, the multipurpose green roof calculations show the pressure on urban water resources could be decreased by fog harvesting mesh and dew collecting PV panels, which could harvest fog/dew/precipitation.

- One of the advantages of green roofs is the thermal impact. However, in the conventional green roofs, the thermal efficiency could decrease in dry periods due to water issues for irrigation, while in the new system, thermal performance improved due to the increase of irrigation in the summer and decrease of water consumption in several ways. First, the installed mesh could absorb fog/dew/precipitation and parts of evapotranspiration by plants. Second, the PV panels could absorb dew water, besides a decrease of direct sunlight toward the green roof. Third, the installed mesh in the specified location of the roofs (in the northern hemisphere is the south side of the roof, and in the southern hemisphere is the north side of the roof) creates a shaded area and could decrease direct sunlight, resulting in decreased water requirements by the green roofs.

- A main part of the fog harvesting cost belongs to the supporting structures for mesh not collapse if high-speed winds should be strong, which affects the final price. However, installing mesh in the building roof does not need a separate structure, decreasing the entire cost of atmospheric water harvesting. Moreover, the potential of fog harvesting depends on the relative humidity. Thus installation in the green roof site with higher relative humidity than the adjacent area could improve fog-harvesting efficiency. Therefore, less cost and higher efficiency could make it a suitable choice for irrigating green roofs and other water demands.

- The average emissivity of solar panels is between $75 \%$ and $90 \%$, making it a suitable choice for dew harvesting. Besides, the dew formation increases near plants. Thus, installing solar PVs on top of a green roof could increase the efficiency of dew collectors. It could also solve another electrical issue, as the high temperature of PV panels decreases, the electricity production efficiency, and the average temperature on the green roof is less than the adjacent area. Therefore, in the new system, the efficiency of both dew collection and electricity by PVs could improve.

- Another issue in the conventional green roofs is the roof area's utilization for other purposes, such as PV panels. In the new design, by specified location of the fog harvesting mesh, the green roof area could be used for solar PV panels, not only for electricity production, but also for dew collection. Moreover, since the condensing plates (PVs) are situated near the plants, the efficiency of dew harvesting also increases.

- Other advantages of green roofs are mitigation of heat islands, water quality improvement, and less air pollution and noise levels. In the new system, the mesh for harvesting fog/dew/precipitations also absorbs noise and air pollutions, improving the conventional green roof's efficiency in decreasing urban air/noise pollution. Moreover, creating a shaded area on the roof could mitigate heat island impacts.

\subsection{Recommendation for Future Studies}

The evaluation of the proposed system's advantages could be assessed through experimental analysis and is recommended for future research. The mesh's impact would not just be water harvesting-since a shaded area on the part of the green roof could 
stop direct sunlight and decrease water usage, as well as improve thermal behavior in the summer; therefore, it is recommended for future studies. Finally, the efficiency of dew collecting by using solar PVs could depend on the type and emissivity; it is recommended for future studies.

\section{Conclusions}

Green roofs have numerous benefits in urban environments; however, confronting certain issues, mainly due to irrigation demands in dry seasons, could put urban water networks under pressure. In addition, less irrigation could negatively affect thermal efficiency, particularly in the summer. The fog and dew harvesting potential in different climates determined the high potential in many geographical locations. While the collected dew amount seems low, it could exceed the precipitation amount since the precipitation in the arid area and other climates during the dry seasons might be less than $1 \mathrm{~mm}$ or zero. Moreover, coated mesh with hydrophilic materials (BaSO4 and $\mathrm{TiO} 2)$ and condensing surfaces with high emissivity and wettability could increase the atmospheric water harvesting efficiency.

The analysis of dew collectors shows an emissivity of more than 0.8 could result in a satisfactory yield. Therefore, solar PVs with the emissivity of $75 \%$ to $90 \%$ could be suitable for dew harvesting. In addition, installing solar PVs on green roofs could improve the electrical efficiency, as the high temperature decreases the efficiency of PVs, and the average temperature on the green roof is less than the adjacent area.

The comparisons among water use of green roofs and atmospheric water harvesting potential reveal the possibility of using these methods to provide a part of green roof water requirements. According to the analysis of the suggested multipurpose green roof combined with fog and dew harvesting systems, in the summer, it seems that installation of the fog harvesting mesh on two sides of the roof could provide the total water requirements of the green roofs. While installing the fog harvesting mesh on the four sides of the roofs could provide more water for other usages, it might negatively affect electricity production efficiency due to the created shaded area on the roof. The dew harvesting analysis by PV panels determined that the maximum potential in providing water requirements of green roofs in the summer could be $25 \%$ in humid climates, $15 \%$ in Mediterranean climates, and $26 \%$ in arid climates. In other seasons, such as winter, the harvested water from fog/dew could be used for the green roof or other non-potable water usages.

In conclusion, it seems that the novel suggested multipurpose green roof, combined with dew/fog harvesting, has several benefits in comparison to conventional ones, including being less dependent on urban water networks, particularly in dry periods, and lower water use due to the shaded area by mesh and solar PVs. Moreover, the new system could show a higher thermal impact on the building, higher efficiency in stormwater management, and greater efficiency in decreasing urban air, water, and noise pollutions. The new multipurpose green roof system could maximize the utilization of the roof area since both green roofs and PV panels could be applied on the same roof.

\section{Patents}

The manuscript's idea was submitted as a patent in Italy, Ministero dello sviluppo economico, with Application number: 102021000000005.

Author Contributions: Conceptualization, B.P.; methodology, B.P.; data curation, B.P., M.T., and S.A.P.; formal analysis, B.P., M.T., and S.A.P.; investigation, B.P., M.T., and S.A.P.; writing-original draft preparation, B.P., M.T., and S.A.P.; writing-review and editing, B.P., M.T., and S.A.P.; supervision, B.P., M.T. All authors have read and agreed to the published version of the manuscript.

Funding: This research received no external funding.

Conflicts of Interest: The authors declare no conflict of interest. 


\section{References}

1. Carbone, M.; Garofalo, G.; Piro, P. Decentralized real time control in combined sewer system by using smart objects. Procedia Eng. 2014, 89, 473-478. [CrossRef]

2. Oberascher, M.; Zischg, J.; Palermo, S.A.; Kinzel, C.; Rauch, W.; Sitzenfrei, R. Smart Rain Barrels: Advanced LID Management Through Measurement and Control. In UDM 2018: New Trends in Urban Drainage Modelling; Green Energy and Technology; Mannina, G., Ed.; Springer: Cham, Switzerland, 2019; pp. 777-782.

3. Manso, M.; Castro-Gomes, J. Green wall systems: A review of their characteristics. Renew. Sustain. Energy Rev. 2015, 41, 863-871. [CrossRef]

4. Li, Y.; Babcock, R.W. Green roof hydrologic performance and modeling: A review. Water Sci. Technol. 2014, 69, 727-738. [CrossRef] [PubMed]

5. Shafique, M.; Kim, R.; Rafiq, M. Green roof benefits, opportunities and challenges-A review. Renew. Sustain. Energy Rev. 2018, 90, 757-773. [CrossRef]

6. Sadeghian, M.M. A Review on Green Wall, Classification and Function. Int. J. Sci. Res. Sci. Technol. 2016, 2, 47-51.

7. Benvenuti, S. Wildflower green roofs for urban landscaping, ecological sustainability and biodiversity. Landsc. Urban Plan. 2014, 124, 151-161. [CrossRef]

8. Mayrand, F.; Clergeau, P. Green roofs and greenwalls for biodiversity conservation: A contribution to urban connectivity? Sustainability 2018, 10, 985. [CrossRef]

9. Hui, S.C.M.; Chan, M.K.L. Biodiversity assessment of green roofs for green building design. In Proceedings of the Joint Symposium 2011: Integrated Building Design in the New Era of Sustainability, Hong Kong, China, 22 November 2011.

10. Fassman-beck, E.; Ph, D.; Simcock, R. Hydrology and Water Quality of Living Roofs in Auckland. NOVATECH 2013, 2013, 1-10.

11. Liu, Y.; Cibin, R.; Bralts, V.F.; Chaubey, I.; Bowling, L.C.; Engel, B.A. Optimal selection and placement of BMPs and LID practices with a rainfall-runoff model. Environ. Model. Softw. 2016, 80, 281-296. [CrossRef]

12. Piro, P.; Carbone, M. A modelling approach to assessing variations of total suspended solids (tss) mass fluxes during storm events. Hydrol. Process. 2014, 28, 2419-2426. [CrossRef]

13. Turco, M.; Brunetti, G.; Porti, M.; Grossi, G.; Maiolo, M.; Piro, P. Metals Potential Removal Efficiency of Permeable Pavement. In New Trends in Urban Drainage Modelling; Springer: Cham, Switzerland, 2019.

14. Falco, S.; Brunetti, G.; Grossi, G.; Maiolo, M.; Turco, M.; Piro, P. Solids removal efficiency of a sedimentation tank in a peri-urban catchment. Sustainability 2020, 12, 7196. [CrossRef]

15. Yang, H.S.; Kang, J.; Choi, M.S. Acoustic effects of green roof systems on a low-profiled structure at street level. Build. Environ. 2012, 50, 44-55. [CrossRef]

16. Veisten, K.; Smyrnova, Y.; Klæboe, R.; Hornikx, M.; Mosslemi, M.; Kang, J. Valuation of green walls and green roofs as soundscape measures: Including monetised amenity values together with noise-attenuation values in a cost-benefit analysis of a green wall affecting courtyards. Int. J. Environ. Res. Public Health 2012, 9, 3770-3788. [CrossRef] [PubMed]

17. Van Renterghem, T.; Botteldooren, D. Reducing the acoustical façade load from road traffic with green roofs. Build. Environ. 2009, 44, 1081-1087. [CrossRef]

18. Ichihara, K.; Cohen, J.P. New York City property values: What is the impact of green roofs on rental pricing? Lett. Spat. Resour. Sci. 2011, 4, 21-30. [CrossRef]

19. Farid, F.H.M.; Ahmad, S.S.; Raub, A.B.A.; Shaari, M.F. Green “Breathing Facades” for Occupants' Improved Quality of Life. Procedia Soc. Behav. Sci. 2016, 234, 173-184. [CrossRef]

20. Tsantopoulos, G.; Varras, G.; Chiotelli, E.; Fotia, K.; Batou, M. Public perceptions and attitudes toward green infrastructure on buildings: The case of the metropolitan area of Athens, Greece. Urban For. Urban Green. 2018, 34, 181-195. [CrossRef]

21. Palermo, S.A.; Talarico, V.C.; Turco, M. On the LID systems effectiveness for urban stormwater management: Case study in Southern Italy. In Proceedings of the IOP Conference Series: Earth and Environmental Science, Thessaloniki, Greece, 23-25 October 2019; Volume 410.

22. Turco, M.; Brunetti, G.; Palermo, S.A.; Capano, G.; Grossi, G.; Maiolo, M.; Piro, P. On the environmental benefits of a permeable pavement: Metals potential removal efficiency and Life Cycle Assessment. Urban Water J. 2020, 17, 619-627. [CrossRef]

23. Pirouz, B.; Palermo, S.A.; Turco, M.; Piro, P. New Mathematical Optimization Approaches for LID Systems. In NUMTA 2019: Numerical Computations: Theory and Algorithm; Lecture Notes in Computer Science; Sergeyev, Y., Kvasov, D., Eds.; Spinger: Cham, Switzerland, 2020; Volume 11973, pp. 583-595.

24. Piro, P.; Carbone, M.; Garofalo, G.; Sansalone, J. CSO treatment strategy based on constituent index relationships in a highly urbanised catchment. Water Sci. Technol. 2007, 56, 85-91. [CrossRef] [PubMed]

25. Turco, M.; Brunetti, G.; Carbone, M.; Piro, P. Modelling the hydraulic behaviour of permeable pavements through a reservoir element model. Int. Multidiscip. Sci. GeoConf. Surv. Geol. Min. Ecol. Manag. 2018, 18, 507-514.

26. Palermo, S.A.; Talarico, V.C.; Pirouz, B. Optimizing Rainwater Harvesting Systems for Non-potable Water Uses and Surface Runoff Mitigation. In NUMTA 2019: Numerical Computations: Theory and Algorithm; Lecture Notes in Computer Science; Sergeyev, Y., Kvasov, D., Eds.; Springer: Cham, Switzerland, 2020; Volume 11973, pp. 570-582.

27. Piro, P.; Turco, M.; Palermo, S.A.; Principato, F.; Brunetti, G. A Comprehensive Approach to Stormwater Management Problems in the Next Generation Drainage Networks. In The Internet of Things for Smart Urban Ecosystems; Springer: Cham, Switzerland, 2019; pp. 275-304. 
28. Stovin, V. The potential of green roofs to manage urban stormwater. Water Environ. J. 2010, 24, 192-199. [CrossRef]

29. Sobczyk, M.; Mrowiec, M. Retention capacity of extensive green roofs. J. Water Land Dev. 2016, 30, 113-117. [CrossRef]

30. Buccola, N.; Spolek, G. A pilot-scale evaluation of greenroof runoff retention, detention, and quality. Water Air Soil Pollut. 2011, 216, 83-92. [CrossRef]

31. Stovin, V.; Vesuviano, G.; Kasmin, H. The hydrological performance of a green roof test bed under UK climatic conditions. J. Hydrol. 2012, 414-415, 148-161. [CrossRef]

32. Locatelli, L.; Mark, O.; Mikkelsen, P.S.; Arnbjerg-Nielsen, K.; Bergen Jensen, M.; Binning, P.J. Modelling of green roof hydrological performance for urban drainage applications. J. Hydrol. 2014, 519, 3237-3248. [CrossRef]

33. Palermo, S.A.; Zischg, J.; Sitzenfrei, R.; Rauch, W.; Piro, P. Parameter Sensitivity of a Microscale Hydrodynamic Model. In UDM 2018: New Trends in Urban Drainage Modelling; Green Energy and Technology; Mannina, G., Ed.; Springer: Cham, Switzerland, 2019; pp. 982-987. [CrossRef]

34. Guattari, C.; Evangelisti, L.; Asdrubali, F.; De Lieto Vollaro, R.L. Experimental evaluation and numerical simulation of the thermal performance of a green roof. Appl. Sci. 2020, 10, 1767. [CrossRef]

35. Pirouz, B.; Palermo, S.A.; Maiolo, M.; Arcuri, N.; Piro, P. Decreasing Water Footprint of Electricity and Heat by Extensive Green Roofs: Case of Southern Italy. Sustainability 2020, 12, 10178. [CrossRef]

36. Arabi, R.; Shahidan, M.; Kamal, M.S.; Jaafar, M.; Rakhshandehroo, M. Mitigating Urban Heat Island Through Green Roofs. Curr. World Environ. 2015, 10, 918-927. [CrossRef]

37. Razzaghmanesh, M.; Beecham, S.; Salemi, T. The role of green roofs in mitigating Urban Heat Island effects in the metropolitan area of Adelaide, South Australia. Urban For. Urban Green. 2016, 15, 89-102. [CrossRef]

38. Susca, T.; Gaffin, S.R.; Dell'Osso, G.R. Positive effects of vegetation: Urban heat island and green roofs. Environ. Pollut. 2011, 159, 2119-2126. [CrossRef] [PubMed]

39. Kolokotsa, D.; Santamouris, M.; Zerefos, S.C. Green and cool roofs' urban heat island mitigation potential in European climates for office buildings under free floating conditions. Sol. Energy 2013, 95, 118-130. [CrossRef]

40. Rozos, E.; Makropoulos, C.; Maksimović, Č. Rethinking urban areas: An example of an integrated blue-green approach. Water Sci. Technol. Water Supply 2013, 13, 1534-1542. [CrossRef]

41. Behzadian, K.; Kapelan, Z.; Venkatesh, G.; Brattebø, H.; Sægrov, S.; Rozos, E.; Makropoulos, C.; Ugarelli, R.; Milina, J.; Hem, L. Urban water system metabolism assessment using WaterMet2 model. Procedia Eng. 2014, 70, 113-122. [CrossRef]

42. Coma, J.; Pérez, G.; Solé, C.; Castell, A.; Cabeza, L.F. Thermal assessment of extensive green roofs as passive tool for energy savings in buildings. Renew. Energy 2016, 85, 1106-1115. [CrossRef]

43. Santamouris, M. Cooling the cities-A review of reflective and green roof mitigation technologies to fight heat island and improve comfort in urban environments. Sol. Energy 2014, 103, 682-703. [CrossRef]

44. Bevilacqua, P.; Bruno, R.; Arcuri, N. Green roofs in a Mediterranean climate: Energy performances based on in-situ experimental data. Renew. Energy 2020, 152, 1414-1430. [CrossRef]

45. Rozos, E.; Tsoukalas, I.; Ripis, K.; Smeti, E.; Makropoulos, C. Turning black into green: Ecosystem services from treated wastewater. Desalin. Water Treat. 2017, 91, 198-205. [CrossRef]

46. Pirouz, B.; Maiolo, M. The role of power consumption and type of air conditioner in direct and indirect water consumption. J. Sustain. Dev. Energy Water Environ. Syst. 2018, 6, 665-673. [CrossRef]

47. Mazzeo, D.; Kontoleon, K.J. The role of inclination and orientation of different building roof typologies on indoor and outdoor environment thermal comfort in Italy and Greece. Sustain. Cities Soc. 2020, 60, 102111. [CrossRef]

48. Choidis, P.; Evgenidis-Karadimitriou, P.; Kontoleon, K.J.; Mazzeo, D. Thermal analysis of flat roof systems with regards to their thermal insulation and exterior surface emissivity coefficient. In Proceedings of the IOP Conference Series: Earth and Environmental Science, Thessaloniki, Greece, 23-25 October 2019.

49. MacIvor, J.S.; Margolis, L.; Perotto, M.; Drake, J.A.P. Air temperature cooling by extensive green roofs in Toronto Canada. Ecol. Eng. 2016, 95, 36-42. [CrossRef]

50. Czemiel Berndtsson, J. Green roof performance towards management of runoff water quantity and quality: A review. Ecol. Eng. 2010, 36, 351-360. [CrossRef]

51. Maiolo, M.; Pirouz, B.; Bruno, R.; Palermo, S.A.; Arcuri, N.; Piro, P. The Role of the Extensive Green Roofs on Decreasing Building Energy Consumption in the Mediterranean Climate. Sustainability 2020, 12, 359. [CrossRef]

52. Nektarios, P.A. Green roofs: Irrigation and maintenance. In Nature Based Strategies for Urban and Building Sustainability; ButterworthHeinemann: Oxford, UK, 2018; pp. 75-84. ISBN 9780128121504. [CrossRef]

53. Pirouz, B.; Turco, M.; Palermo, S.A. A Novel Idea for Improving the Efficiency of Green Walls in Urban Environment (an Innovative Design and Technique). Water 2020, 12, 3524. [CrossRef]

54. Carbone, M.; Turco, M.; Brunetti, G.; Piro, P. A Cumulative Rainfall Function for Subhourly Design Storm in Mediterranean Urban Areas. Adv. Meteorol. 2015, 2015, 1-10. [CrossRef]

55. Reitano, R. Water harvesting and water collection systems in Mediterranean area. the case of Malta. Procedia Eng. 2011, 21, 81-88. [CrossRef]

56. Jarimi, H.; Powell, R.; Riffat, S. Review of sustainable methods for atmospheric water harvesting. Int. J. Low Carbon Technol. 2020, 15, 253-276. [CrossRef] 
57. Zhou, X.; Lu, H.; Zhao, F.; Yu, G. Atmospheric Water Harvesting: A Review of Material and Structural Designs. ACS Mater. Lett. 2020, 2, 671-684. [CrossRef]

58. Tu, Y.; Wang, R.; Zhang, Y.; Wang, J. Progress and Expectation of Atmospheric Water Harvesting. Joule 2018, 2, 1452-1475. [CrossRef]

59. Batisha, A.F. Feasibility and sustainability of fog harvesting. Sustain. Water Qual. Ecol. 2015, 6, 1-10. [CrossRef]

60. Abdul-Wahab, S.A.; Lea, V. Reviewing fog water collection worldwide and in Oman. Int. J. Environ. Stud. 2008, 65, 487-500. [CrossRef]

61. Beysens, D.; Clus, O.; Mileta, M.; Milimouk, I.; Muselli, M.; Nikolayev, V.S. Collecting dew as a water source on small islands: The dew equipment for water project in Biševo (Croatia). Energy 2007, 32, 1032-1037. [CrossRef]

62. Tomaszkiewicz, M.; Abou Najm, M.; Beysens, D.; Alameddine, I.; Bou Zeid, E.; El-Fadel, M. Projected climate change impacts upon dew yield in the Mediterranean basin. Sci. Total Environ. 2016, 566, 1339-1348. [CrossRef]

63. Hill, A.J.; Dawson, T.E.; Shelef, O.; Rachmilevitch, S. The role of dew in Negev Desert plants. Oecologia 2015, 178, 317-327. [CrossRef]

64. Tomaszkiewicz, M.; Abou Najm, M.; Beysens, D.; Alameddine, I.; El-Fadel, M. Dew as a sustainable non-conventional water resource: A critical review. Environ. Rev. 2015, 23, 425-442. [CrossRef]

65. Zhuang, Y.; Zhao, W. Dew formation and its variation in Haloxylon ammodendron plantations at the edge of a desert oasis, northwestern China. Agric. For. Meteorol. 2017, 247, 541-550. [CrossRef]

66. Ilse, K.; Figgis, B.; Khan, M.Z.; Naumann, V.; Hagendorf, C. Dew as a Detrimental Influencing Factor for Soiling of PV Modules. IEEE J. Photovolt. 2019, 9, 287-294. [CrossRef]

67. Riverola, A.; Mellor, A.; Alonso Alvarez, D.; Ferre Llin, L.; Guarracino, I.; Markides, C.N.; Paul, D.J.; Chemisana, D.; Ekins-Daukes, N. Mid-infrared emissivity of crystalline silicon solar cells. Sol. Energy Mater. Sol. Cells 2018, 174, 607-615. [CrossRef]

68. Subedi, I.; Silverman, T.J.; Deceglie, M.G.; Podraza, N.J. Emissivity of solar cell cover glass calculated from infrared reflectance measurements. Sol. Energy Mater. Sol. Cells 2019, 190, 98-102. [CrossRef]

69. Hossain, M.A.; Shams, S.; Amin, M.; Reza, M.S.; Chowdhury, T.U. Perception and barriers to implementation of intensive and extensive green roofs in Dhaka, Bangladesh. Buildings 2019, 9, 79. [CrossRef]

70. Brunetti, G.; Turco, M.; Carbone, M.; Maiolo, M.; Piro, P. Modelling the hydraulic behaviour of green roofs through a semiconceptual reservoir element model. Int. Multidiscip. Sci. GeoConf. 2018, 18, 499-506.

71. Cascone, S. Green roof design: State of the art on technology and materials. Sustainability 2019, 11, 3020. [CrossRef]

72. Palla, A.; Gnecco, I. Hydrologic modeling of Low Impact Development systems at the urban catchment scale. J. Hydrol. 2015, 528, 361-368. [CrossRef]

73. Palla, A.; Sansalone, J.J.; Gnecco, I.; Lanza, L.G. Storm water infiltration in a monitored green roof for hydrologic restoration. Water Sci. Technol. 2011, 64, 766-773. [CrossRef] [PubMed]

74. Fioretti, R.; Palla, A.; Lanza, L.G.; Principi, P. Green roof energy and water related performance in the Mediterranean climate. Build. Environ. 2010, 45, 1890-1904. [CrossRef]

75. Coma, J.; Pérez, G.; de Gracia, A.; Burés, S.; Urrestarazu, M.; Cabeza, L.F. Vertical greenery systems for energy savings in buildings: A comparative study between green walls and green facades. Build. Environ. 2017, 111, 228-237. [CrossRef]

76. Pérez, G.; Coma, J.; Sol, S.; Cabeza, L.F. Green facade for energy savings in buildings: The influence of leaf area index and facade orientation on the shadow effect. Appl. Energy 2017, 187, 424-437. [CrossRef]

77. Perini, K.; Bazzocchi, F.; Croci, L.; Magliocco, A.; Cattaneo, E. The use of vertical greening systems to reduce the energy demand for air conditioning. Field monitoring in Mediterranean climate. Energy Build. 2017, 143, 35-42. [CrossRef]

78. Manso, M.; Teotónio, I.; Silva, C.M.; Cruz, C.O. Green roof and green wall benefits and costs: A review of the quantitative evidence. Renew. Sustain. Energy Rev. 2021, 135, 110111. [CrossRef]

79. Wong, N.H.; Cheong, D.K.W.; Yan, H.; Soh, J.; Ong, C.L.; Sia, A. The effects of rooftop garden on energy consumption of a commercial building in Singapore. Energy Build. 2003, 35, 353-364. [CrossRef]

80. Zaid, S.M.; Perisamy, E.; Hussein, H.; Myeda, N.E.; Zainon, N. Vertical Greenery System in urban tropical climate and its carbon sequestration potential: A review. Ecol. Indic. 2018, 91, 57-70. [CrossRef]

81. Qin, X. A Green Roof Test Bed for Stormwater Management and Reduction of Urban Heat Island Effect in Singapore. Br. J. Environ. Clim. Chang. 2013, 2, 410-420. [CrossRef]

82. Kasmin, H.; Stovin, V.; De-ville, S. Evaluation of Green Roof Hydrological Performance in a Malaysian Context; Borneo Convention Centre Kuching (BCCK): Sarawak, Malaysia, 7-12 September 2014; pp. 1-9.

83. Wong, N.H.; Kwang Tan, A.Y.; Chen, Y.; Sekar, K.; Tan, P.Y.; Chan, D.; Chiang, K.; Wong, N.C. Thermal evaluation of vertical greenery systems for building walls. Build. Environ. 2010, 45, 663-672. [CrossRef]

84. Zinzi, M.; Agnoli, S. Cool and green roofs. An energy and comfort comparison between passive cooling and mitigation urban heat island techniques for residential buildings in the Mediterranean region. Energy Build. 2012, 55, 66-76. [CrossRef]

85. Sims, A.W.; Robinson, C.E.; Smart, C.C.; Voogt, J.A.; Hay, G.J.; Lundholm, J.T.; Powers, B.; O'Carroll, D.M. Retention performance of green roofs in three different climate regions. J. Hydrol. 2016, 542, 115-124. [CrossRef]

86. Alexandri, E.; Jones, P. Temperature decreases in an urban canyon due to green walls and green roofs in diverse climates. Build. Environ. 2008, 43, 480-493. [CrossRef] 
87. Mazzeo, D.; Oliveti, G. Thermal field and heat storage in a cyclic phase change process caused by several moving melting and solidification interfaces in the layer. Int. J. Therm. Sci. 2018, 129, 462-488. [CrossRef]

88. Mazzeo, D.; Matera, N.; De Luca, P.; Baglivo, C.; Maria Congedo, P.; Oliveti, G. Worldwide geographical mapping and optimization of stand-alone and grid-connected hybrid renewable system techno-economic performance across Köppen-Geiger climates. Appl. Energy 2020, 276, 115507. [CrossRef]

89. Mazzeo, D.; Oliveti, G. Parametric study and approximation of the exact analytical solution of the Stefan problem in a finite PCM layer in a steady periodic regime. Int. Commun. Heat Mass Transf. 2017, 84, 49-65. [CrossRef]

90. Brunetti, G.; Porti, M.; Piro, P. Multi-level numerical and statistical analysis of the hygrothermal behavior of a non-vegetated green roof in a mediterranean climate. Appl. Energy 2018, 221, 204-219. [CrossRef]

91. Schweitzer, O.; Erell, E. Evaluation of the energy performance and irrigation requirements of extensive green roofs in a waterscarce Mediterranean climate. Energy Build. 2014, 68, 25-32. [CrossRef]

92. Peng, L.L.H.; Jim, C.Y. Seasonal and diurnal thermal performance of a subtropical extensive green roof: The impacts of background weather parameters. Sustainability 2015, 7, 11098-11113. [CrossRef]

93. Tomaszkiewicz, M.; Abou Najm, M.; Zurayk, R.; El-Fadel, M. Dew as an adaptation measure to meet water demand in agriculture and reforestation. Agric. For. Meteorol. 2017, 232, 411-421. [CrossRef]

94. Maestre-Valero, J.F.; Martínez-Alvarez, V.; Baille, A.; Martín-Górriz, B.; Gallego-Elvira, B. Comparative analysis of two polyethylene foil materials for dew harvesting in a semi-arid climate. J. Hydrol. 2011, 410, 84-91. [CrossRef]

95. Maestre-Valero, J.F.; Ragab, R.; Martínez-Alvarez, V.; Baille, A. Estimation of dew yield from radiative condensers by means of an energy balance model. J. Hydrol. 2012, 460, 103-109. [CrossRef]

96. Maestre-Valero, J.F.; Martin-Gorriz, B.; Martínez-Alvarez, V. Dew condensation on different natural and artificial passive surfaces in a semiarid climate. J. Arid Environ. 2015, 116, 63-70. [CrossRef]

97. Sharan, G.; Clus, O.; Singh, S.; Muselli, M.; Beysens, D. A very large dew and rain ridge collector in the Kutch area (Gujarat, India). J. Hydrol. 2011, 405, 171-181. [CrossRef]

98. Tuure, J.; Korpela, A.; Hautala, M.; Rautkoski, H.; Hakojärvi, M.; Mikkola, H.; Duplissy, J.; Pellikka, P.; Petäjä, T.; Kulmala, M.; et al. Comparing plastic foils for dew collection: Preparatory laboratory-scale method and field experiment in Kenya. Biosyst. Eng. 2020, 196, 145-158. [CrossRef]

99. Gandhidasan, P.; Abualhamayel, H.I. Modeling and testing of a dew collection system. Desalination 2005, 180, 47-51. [CrossRef]

100. Gałek, G.; Sobik, M.; Błaś, M.; Polkowska, Z.; Cichała-Kamrowska, K.; Wałaszek, K. Dew and hoarfrost frequency, formation efficiency and chemistry in Wroclaw, Poland. Atmos. Res. 2015, 151, 120-129. [CrossRef]

101. Pinheiro, R.A.; Rosa, F.M.; Volú, R.M.; de Vasconcelos, G.; Trava-Airoldi, V.J.; Corat, E.J. Vertically aligned carbon nanotubes (VACNT) surfaces coated with polyethylene for enhanced dew harvesting. Diam. Relat. Mater. 2020, 107, 107837. [CrossRef]

102. Liu, C.; Fan, J.; Bao, H. Hydrophilic radiative cooler for direct water condensation in humid weather. Sol. Energy Mater. Sol. Cells 2020, 216, 110700. [CrossRef]

103. Xu, P.; Ma, X.; Zhao, X.; Xiong, Y.; Sun, Y. Feasibility analysis for a novel dew point air cooler applied in warm and humid climate: A case study in Beijing. Energy Procedia 2019, 158, 2126-2131. [CrossRef]

104. Pandelidis, D.; Niemierka, E.; Pacak, A.; Jadwiszczak, P.; Cichon, A.; Drag, P.; Worek, W.; Cetin, S. Performance study of a novel dew point evaporative cooler in the climate of central Europe using building simulation tools. Build. Environ. 2020, 181, 107101. [CrossRef]

105. Jacobs, A.F.G.; Heusinkveld, B.G.; Berkowicz, S.M. A simple model for potential dewfall in an arid region. Atmos. Res. 2002, 64, 285-295. [CrossRef]

106. Beysens, D. Estimating dew yield worldwide from a few meteo data. Atmos. Res. 2016, 167, 146-155. [CrossRef]

107. Agam, N.; Berliner, P.R. Dew formation and water vapor adsorption in semi-arid environments-A review. J. Arid Environ. 2006, 65, 572-590. [CrossRef]

108. Nilsson, T.M.J.; Vargas, W.E.; Niklasson, G.A.; Granqvist, C.G. Condensation of water by radiative cooling. Renew. Energy 1994, 5, 310-317. [CrossRef]

109. Seo, D.; Lee, J.; Lee, C.; Nam, Y. The effects of surface wettability on the fog and dew moisture harvesting performance on tubular surfaces. Sci. Rep. 2016, 6, 1-11. [CrossRef]

110. Lobo, A.O.; Ramos, S.C.; Antunes, E.F.; Marciano, F.R.; Trava-Airoldi, V.J.; Corat, E.J. Fast functionalization of vertically aligned multiwalled carbon nanotubes using oxygen plasma. Mater. Lett. 2012, 70, 89-93. [CrossRef]

111. Trojanowicz, M. Analytical applications of carbon nanotubes: A review. TrAC Trends Anal. Chem. 2006, 25, 480-489. [CrossRef]

112. Beysens, D.; Broggini, F.; Milimouk-Melnytchouk, I.; Ouazzani, J.; Tixier, N. New architectural forms to enhance dew collection. Chem. Eng. Trans. 2013, 34, 79-84.

113. Eriksson, T.S.; Granqvist, C.G. Radiative cooling computed for model atmospheres. Appl. Opt. 1982, 21, 4381-4388. [CrossRef] [PubMed]

114. Jones, H.G. Plants and Microclimate: A Quantitative Approach to Environmental Plant Physiology; Cambridge University Press: Cambridge, UK, 2013; ISBN 9780511845727.

115. Muselli, M.; Beysens, D.; Milimouk, I. A comparative study of two large radiative dew water condensers. J. Arid Environ. 2006, 64, 54-76. [CrossRef] 
116. Schemenauer, R.S.; Cereceda, P. A Proposed Standard Fog Collector for Use in High-Elevation Regions. J. Appl. Meteorol. 1994, 33, 1313-1322. [CrossRef]

117. Klemm, O.; Schemenauer, R.S.; Lummerich, A.; Cereceda, P.; Marzol, V.; Corell, D.; Van Heerden, J.; Reinhard, D.; Gherezghiher, T.; Olivier, J.; et al. Fog as a fresh-water resource: Overview and perspectives. Ambio 2012, 41, 221-234. [CrossRef] [PubMed]

118. Harb, O.M.; Salem, M.S.; Abd EL-Hay, G.H.; Makled, K.M. Fog water harvesting providing stability for small Bedwe communities lives in North cost of Egypt. Ann. Agric. Sci. 2016, 61, 105-110. [CrossRef]

119. Lekouch, I.; Lekouch, K.; Muselli, M.; Mongruel, A.; Kabbachi, B.; Beysens, D. Rooftop dew, fog and rain collection in southwest Morocco and predictive dew modeling using neural networks. J. Hydrol. 2012, 448, 60-72. [CrossRef]

120. Park, K.C.; Chhatre, S.S.; Srinivasan, S.; Cohen, R.E.; McKinley, G.H. Optimal design of permeable fiber network structures for fog harvesting. Langmuir 2013, 29, 13269-13277. [CrossRef] [PubMed]

121. Regalado, C.M.; Ritter, A. On the estimation of potential fog water collection from meteorological variables. Agric. For. Meteorol. 2019, 276, 107645. [CrossRef]

122. de Dios Rivera, J. Aerodynamic collection efficiency of fog water collectors. Atmos. Res. 2011, 102, 335-342. [CrossRef]

123. Rajaram, M.; Heng, X.; Oza, M.; Luo, C. Enhancement of fog-collection efficiency of a Raschel mesh using surface coatings and local geometric changes. Colloids Surf. A Physicochem. Eng. Asp. 2016, 508, 218-229. [CrossRef]

124. Estrela, M.J.; Valiente, J.A.; Corell, D.; Millán, M.M. Fog collection in the western Mediterranean basin (Valencia region, Spain). Atmos. Res. 2008, 87, 324-337. [CrossRef]

125. Zhou, H.; Jing, X.; Guo, Z. Excellent fog droplets collector via an extremely stable hybrid hydrophobic-hydrophilic surface and Janus copper foam integrative system with hierarchical micro/nanostructures. J. Colloid Interface Sci. 2020, 561, 730-740. [CrossRef] [PubMed]

126. Almasian, A.; Chizari Fard, G.; Mirjalili, M.; Parvinzadeh Gashti, M. Fluorinated-PAN nanofibers: Preparation, optimization, characterization and fog harvesting property. J. Ind. Eng. Chem. 2018, 62, 146-155. [CrossRef]

127. Ghosh, R.; Sahu, R.P.; Ganguly, R.; Zhitomirsky, I.; Puri, I.K. Photocatalytic activity of electrophoretically deposited TiO2 and ZnO nanoparticles on fog harvesting meshes. Ceram. Int. 2020, 46, 3777-3785. [CrossRef]

128. Ghosh, R.; Ray, T.K.; Ganguly, R. Cooling tower fog harvesting in power plants-A pilot study. Energy 2015, 89, 1018-1028. [CrossRef]

129. Pinheiro, R.A.; Silva, A.A.; Trava-Airoldi, V.J.; Corat, E.J. Water vapor condensation and collection by super-hydrophilic and super-hydrophobic VACNTs. Diam. Relat. Mater. 2018, 87, 43-49. [CrossRef]

130. Pirouz, B.; Arcuri, N.; Pirouz, B.; Palermo, S.A.; Turco, M.; Maiolo, M. Development of an assessment method for evaluation of sustainable factories. Sustainability 2020, 12, 1841. [CrossRef]

131. Pirouz, B.; Arcuri, N.; Maiolo, M.; Talarico, V.C.; Piro, P. A new multi-objective dynamic model to close the gaps in sustainable development of industrial sector. In Proceedings of the IOP Conference Series: Earth and Environmental Science, Thessaloniki, Greece, 23-25 October 2019.

132. Getter, K.L.; Rowe, D.B. The role of extensive green roofs in sustainable development. HortScience 2006, 41, 1276-1285. [CrossRef]

133. de Dios Rivera, J.; Lopez-Garcia, D. Mechanical characteristics of Raschel mesh and their application to the design of large fog collectors. Atmos. Res. 2015, 151, 250-258. [CrossRef]

134. Sendo, T.; Kanechi, M.; Uno, Y.; Inagaki, N. Evaluation of Growth and Green Coverage of Ten Ornamental Species for Planting as Urban Rooftop Greening. J. Jpn. Soc. Hortic. Sci. 2010, 79, 69-76. [CrossRef]

135. Feng, C.; Yao, R.; Zhang, Y. Analysis on the impact of roof greening's water consumption made by meteorological factor. In Proceedings of the 2012 International Conference on Computer Distributed Control and Intelligent Environmental Monitoring, Zhangjiajie, China, 5-6 March 2012; pp. 142-144.

136. Kaiser, D.; Köhler, M.; Schmidt, M.; Wolff, F. Increasing Evapotranspiration on Extensive Green Roofs by Changing Substrate Depths, Construction, and Additional Irrigation. Buildings 2019, 9, 173. [CrossRef]

137. Kotsiris, G.; Nektarios, P.A.; Ntoulas, N.; Kargas, G. An adaptive approach to intensive green roofs in the Mediterranean climatic region. Urban For. Urban Green. 2013, 12, 380-392. [CrossRef]

138. Papafotiou, M.; Pergialioti, N.; Tassoula, L.; Massas, I.; Kargas, G. Growth of native aromatic xerophytes in an extensive Mediterranean green roof as affected by substrate type and depth and irrigation frequency. HortScience 2013, 48, 1327-1333. [CrossRef]

139. Bousselot, J.M.; Klett, J.E.; Koski, R.D. Extensive green roof species evaluations using digital image analysis. HortScience 2010, 45, 1288-1292. [CrossRef]

140. Sharan, G. Harvesting Dew with Radiation Cooled Condensers to Supplement Drinking Water Supply in Semi-arid. Int. J. Serv. Learn. Eng. Humanit. Eng. Soc. Entrep. 2011, 6, 130-150. [CrossRef]

141. Muselli, M.; Beysens, D.; Marcillat, J.; Milimouk, I.; Nilsson, T.; Louche, A. Dew water collector for potable water in Ajaccio (Corsica Island, France). Atmos. Res. 2002, 64, 297-312. [CrossRef]

142. Beysens, D.; Muselli, M.; Milimouk, I.; Ohayon, C.; Berkowicz, S.M.; Soyeux, E.; Mileta, M.; Ortega, P. Application of passive radiative cooling for dew condensation. Energy 2006, 31, 2303-2315. [CrossRef]

143. Clus, O.; Ortega, P.; Muselli, M.; Milimouk, I.; Beysens, D. Study of dew water collection in humid tropical islands. J. Hydrol. 2008, 361, 159-171. [CrossRef] 
144. Tuure, J.; Korpela, A.; Hautala, M.; Hakojärvi, M.; Mikkola, H.; Räsänen, M.; Duplissy, J.; Pellikka, P.; Petäjä, T.; Kulmala, M.; et al. Comparison of surface foil materials and dew collectors location in an arid area: A one-year field experiment in Kenya. Agric. For. Meteorol. 2019, 276, 107613. [CrossRef]

145. Larrain, H.; Velásquez, F.; Cereceda, P.; Espejo, R.; Pinto, R.; Osses, P.; Schemenauer, R.S. Fog measurements at the site "Falda Verde" north of Chañaral compared with other fog stations of Chile. Atmos. Res. 2002, 64, 273-284. [CrossRef]

146. Calderón, M.; Cereceda, P.; Larrain, H.; Osses, P.; Pérez, L.; Ibáñez, M. Alto Patache fog oasis in the Atacama Desert: Geographical basis for a sustainable development program. In Proceedings of the 5th International Conference on Fog, Fog Collection and Dew, Münster, Germany, 25-30 July 2010.

147. Cereceda, P.; Larrain, H.; Osses, P.; Farías, M.; Egaña, I. The spatial and temporal variability of fog and its relation to fog oases in the Atacama Desert, Chile. Atmos. Res. 2008, 87, 312-323. [CrossRef]

148. Khaledi, C.K.A. Projection of harvestable water from air humidity using artificial neural network (Case study: Chabahar port). Ital. J. Agrometeorol. 2019, 3-11. [CrossRef]

149. Sabino, A. Fog collection in the natural park of Serra Malagueta. An alternative source of water for the communities. In Proceedings of the 4th International Conference on Fog, Fog Collection and Dew, La Serena, Chile, 22-27 July 2007; pp. 425-428.

150. Davtalab, R.; Salamat, A.; Oji, R. Water harvesting from fog and air humidity in the warm and coastal regions in the south of iran. Irrig. Drain. 2013, 62, 281-288. [CrossRef]

151. Dodson, L.L.; Bargach, J. Harvesting Fresh Water from Fog in Rural Morocco: Research and Impact Dar Si Hmad's Fogwater Project in Aït Baamrane. Procedia Eng. 2015, 107, 186-193. [CrossRef]

152. Olivier, J.; De Rautenbach, C.J. The implementation of fog water collection systems in South Africa. Atmos. Res. 2002, 64, 227-238. [CrossRef]

153. Fessehaye, M.; Abdul-Wahab, S.A.; Savage, M.J.; Kohler, T.; Gherezghiher, T.; Hurni, H. Fog-water collection for community use. Renew. Sustain. Energy Rev. 2014, 29, 52-62. [CrossRef]

154. Tony New Tojquia Project Completed. 2020. Available online: http:/ /www.fogquest.org/latest-news/ (accessed on 15 January 2021).

155. Schemenauer, R.S.; Osses, P.; Leibbrand, M. Fog Collection Evaluation and Operational Projects in the Hajja Governorate, Yemen. In Proceedings of the Third International Conference on Fog, Fog Collection and Dew, Cape Town, South Africa, 11-15 October 2004.

156. FogQuest. Sustainable Water Solutions; FogQuest: Kamloops, BC, Canada, 2007.

157. Di Bitonto, M.G.; Angelotti, A.; Zanelli, A. Fog and Dew Harvesting: Italy and Chile in Comparison. Int. J. Innov. Res. Dev. 2020, 9, 132-140. [CrossRef]

158. Bagheri, F. Performance investigation of atmospheric water harvesting systems. Water Resour. Ind. 2018, 20, 23-28. [CrossRef] 